\title{
An Examination of Extreme Flood Events and Resiliency of the Middle St. Johns River, Florida USA Using Multiple Methods
}

\author{
Wesley Koning 1, Christopher Brown 1,*, Wesley Koning 1, Cigdem Akan 2, Patrick Kreidl ${ }^{3}$ \\ ${ }^{1}$ School of Engineering, University of North Florida, USA; n01051302@unf.edu \\ ${ }^{2}$ Taylor Engineering Research Institute, University of North Florida, USA; cigdem.akan@unf.edu \\ ${ }^{3}$ School of Engineering, University of North Florida, USA; patrick.kreidl@unf.edu \\ * Correspondence: christopher.j.brown@unf.edu; Tel.: +01-904-620-2811
}

\begin{abstract}
The middle portion of the St. Johns River is located in East-Central Florida, USA. This region of the St. Johns River is increasingly subject to urbanization and conversion of forest areas to agricultural land. Overall, these changes mean that future flood events in the area could adversely impact local citizens. Therefore, the examination of extreme flood events and resiliency to such events is critically important. The purpose of this preliminary study is to explore a range of practical applications to estimate extreme flood events at locations within the Middle St. Johns River Basin, focusing specifically upon the Wekiva River sub-basin (located just west of Lake Mary, Florida). The current work illustrates the overall technical methodology and provides preliminary estimates of extreme flood events at different return frequencies using two statistical approaches. Future work will also estimate the magnitude of extreme flood events via model simulations utilizing an existing Wekiva River HSPF rainfall-runoff model previously developed by the Saint Johns River Water Management District. Altogether, once fully integrated and complete, the methods will permit prediction of a range of possible flood discharges at any place along the Wekiva watercourse.
\end{abstract}

Keywords: St. Johns River; model; estimate; surface water; system model; flood simulation

\section{Introduction}

The Wekiva sub-basin is located in portions of Orange, Seminole, Polk, Lake, and Marion counties. This planning unit is comprised of 974 square kilometers, with three major watercourses: the Wekiva River, the Little Wekiva River, and Black Water Creek. Wetlands and rural land populate the majority of the surrounding areas near the Wekiva River and Black Water Creek. The Little Wekiva River outputs to the Wekiva river, extending its presence through multiple residential areas and larger urbanized plots of land. Figure 1 shows the general location of the watershed within Florida, situating itself between Orlando and Daytona Beach, Florida USA. 


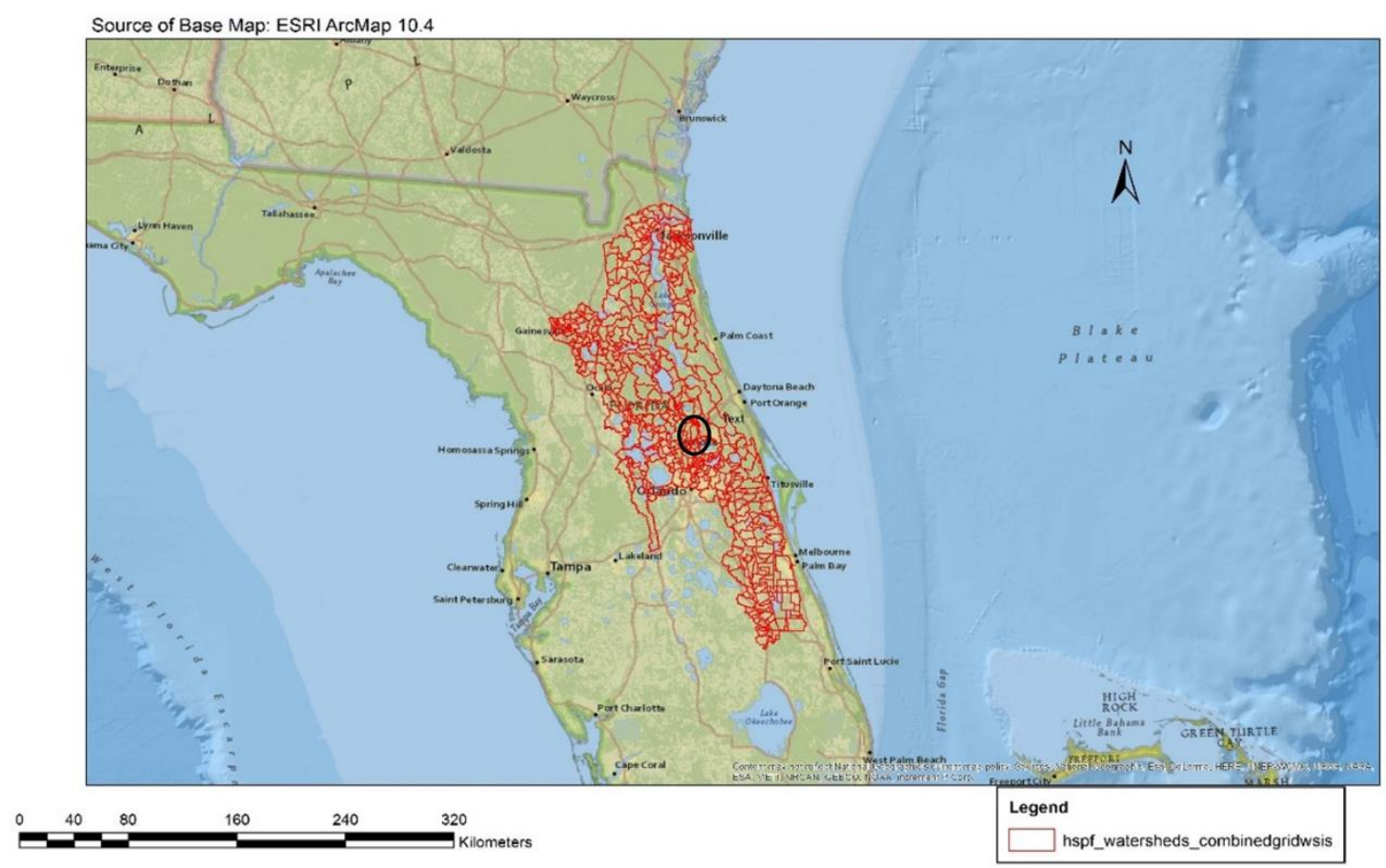

Figure 1. General location of the Wekiva sub-basin (circled) in Florida.

Through gathered information and literature, our team was able to analyze the Wekiva subbasin to identify if a reliable statistical equation could be implemented to accurately estimate the effects of extreme storm events. Discussing historical published reports will lead the team to decide if the statistical methods considered were reasonable alternative estimates. This is important since other areas of the watershed do not have any published extreme flood estimates. The statistical tests will be deemed acceptable only if similar results are indicated from the published data.

\section{Prior Publications}

\subsection{Federal Emergency Management Agency (FEMA)}

To analyze the risk of flooding within a given community, FEMA performs an engineering assessment called a Flood Insurance Study (FIS). The FIS is a collection of flood hazard areas along rivers, streams, and coasts. FEMA became nationally recognized, contributing to what is now known as its risk mapping, assessment, and planning. The flood maps generated by FEMA constitute as an important part of the National Flood Insurance Program (NFIP) regulations and flood insurance requirements. A FEMA flood map informs the community about local flood risks, while also issuing the minimum floodplain standards that will allow a community to build safely and resiliently [1]. Due to ever changing environmental factors, population growth, and evolving engineering practices, a watershed could be reassessed and remapped by FEMA if it necessary. For this project location, it is important that the Wekiva River, Little Wekiva River, and Black Water Creek have documented studies that pertain to its flow characteristics. Further investigation establishes that the project location has a joining county line on the Wekiva River, contributing to the assessment of two FIS reports in both Lake County [1] and Seminole County [2]. Through the study it became apparent that neither the Wekiva River nor the Black Water Creek run through heavily populated communities. Because communities were not at risk, no publications were collected for either of the two aforementioned watercourses. However, the Little Wekiva River had risk acquired for multiple communities and so an FIS was developed and published. FEMA's estimated flood discharges at various return frequencies were taken at the Little Wekiva River on State Road 434 and detailed in Table 1. 
Table 1. FEMA FIS output estimates at the Little Wekiva River for various 24-hr duration storm events.

\begin{tabular}{|c|c|c|c|c|c|}
\hline & & \multicolumn{4}{|c|}{ Peak Discharges } \\
\hline Little Wekiva River & Drainage Area & $10-\mathrm{yr}$ & $25-\mathrm{yr}$ & $50-\mathrm{yr}$ & $100-\mathrm{yr}$ \\
\hline At State Route 434 & $87.54 \mathrm{sq} . \mathrm{km}$ & $26.04 \mathrm{cms}$ & $33.19 \mathrm{cms}$ & $42.45 \mathrm{cms}$ & $50.94 \mathrm{cms}$ \\
\hline
\end{tabular}

The acquired data provides a baseline in the team's attempt to estimate the flood discharge rates using statistical equations. Obtaining the 10-year (yr), 25-yr, 50-yr, and 100-yr flood events on the Little Wekiva River is very helpful in understanding the flow that this waterway presents as well as the overall risk of flooding to adjacent communities.

\subsection{St. Johns River Water Management District (SJRWMD)}

The SJRWMD is required by law to establish minimum surface water flows, flow levels, and minimum ground water levels for the Floridan aquifer system within the Wekiva Basin (Paragraph 373.415[3], Florida Statutes [FS]) [3]. SJRWMD uses the modeling software called Hydrological Simulation Program - FORTRAN (HSPF) to simulate existing and future conditions. HSPF is a plugin of Better Assessment Science Integrating Point and Nonpoint Sources (BASINS) and is very powerful at interpolating data among the river where gauges are not present. SJRWMD has input all watershed characteristics into this model based upon the observed hydrology, hydraulic conditions, and geotechnical results. Furthermore, a report was created displaying the description of flow rates and flood profiles at the 10-yr and 100-yr 24-hour duration storm events at many locations [4]. Table 2 depicts the point of interest on the Little Wekiva River that can easily be compared to the FEMA estimates.

Table 2. SJRWMD and FEMA comparison of the Little Wekiva River discharge for 10-year and 100year storm events.

\begin{tabular}{|c|c|c|c|c|c|}
\hline & & \multicolumn{4}{c|}{ Peak Discharges } \\
\hline \multirow{2}{*}{} & & \multicolumn{3}{c|}{$10-\mathrm{yr}$} & \multicolumn{2}{c|}{$100-\mathrm{yr}$} \\
\hline Little Wekiva River & Drainage Area & SJRWMD & FEMA & SJRWMD & FEMA \\
\hline At State Route 434 & 87.54 sq. km & $28.58 \mathrm{cms}$ & $26.04 \mathrm{cms}$ & $72.45 \mathrm{cms}$ & $50.94 \mathrm{cms}$ \\
\hline
\end{tabular}

\section{Statistical Calculations}

This research is devoted to finding a method that can accurately estimate flood events caused by extreme flood events. Two particular methods have been chosen for further analysis. The first is the Log Pearson Type III method, a method that has been known as the United States of America's official model for decades now [5]. The second is the Power Law method, this method was selected since it is simple to implement but still provides high accuracy outputs when conducting calculations for natural waterways. The Power Law method is known to be ideal during extreme storm events but has trouble when a storm event nears its mean discharge rates [5]. The Power Law methodology can be used in both linear and non-linear regression models as was the case in this research study. Both methods (e.g. Log Pearson Type III and Power Law) permit estimates of flow rates at particular gaged locations within the Wekiva sub-basin. The estimates made using the two statistical methods are then compared to published discharge rates from FEMA and the SJRWMD. Any distinct similarities or differences will be noted and then discussed. Altogether, these statistical tests are relatively similar in initial calculations; including peak discharge values, ranking, and Weibull plotting position. Essentially, calculations involve several steps. Maximum daily discharge values were selected for each year of the available period of record, which included 34 years in this study area. The data provided included observed data from stream gages and synthetic data extracted from an HSPF simulation completed previously by the SJRWMD and graciously provided by them. Then, for the Log Pearson Type III method, a sequence of calculations was needed to determine the variation, standard deviation, and skew coefficient. While the Power Law method directed its 
attention to determining the $\mathrm{C}$ and Alpha coefficients through two different ways, Solver Non-Linear Regression and Linear Regression, both processes still provide relatively similar outputs at smaller storm events while at larger storm event (greater than a 25-yr storm) the outputs started to differentiate in flow rates. This will be further examined in the next section to gain an understanding of the true direction each method takes.

\section{Results}

The basis of this experiment relied on data that was solid and had been around for multiple years. Calibration of the statistical model was initialized in the region around the Little Wekiva River for which the FEMA FIS and SJRWMD publications are available. The Little Wekiva River at State Road 434 (USGS Gage 2234990) was chosen since there were published estimates. This made it a meaningful location to compare the statistical results to the historical estimates. Following in Table 3 are the estimates depicted by the statistical tests developed for this study and those from the previous FEMA and SJRWMD reports.

Table 3. Comparing Discharge Results on the Little Wekiva River at State Road 434.

\begin{tabular}{cc|c|c|c|c}
\hline \multicolumn{2}{|c|}{ Storm Event } & $10-\mathrm{yr}$ & $25-\mathrm{yr}$ & $50-\mathrm{yr}$ & $100-\mathrm{yr}$ \\
\hline \multirow{2}{*}{ Power Law } & $\mathbf{Q}$ (Solver) & $20.07 \mathrm{cms}$ & $28.71 \mathrm{cms}$ & $37.64 \mathrm{cms}$ & $49.35 \mathrm{cms}$ \\
\cline { 2 - 6 } & $\mathbf{Q}$ (Lin. R) & $22.44 \mathrm{cms}$ & $36.00 \mathrm{cms}$ & $51.47 \mathrm{cms}$ & $73.58 \mathrm{cms}$ \\
\hline Log Pearson Type III & $20.33 \mathrm{cms}$ & $25.83 \mathrm{cms}$ & $30.22 \mathrm{cms}$ & $34.87 \mathrm{cms}$ \\
\hline FEMA Q & $26.04 \mathrm{cms}$ & $33.19 \mathrm{cms}$ & $42.45 \mathrm{cms}$ & $50.94 \mathrm{cms}$ \\
\hline SJRWMD Q & $28.58 \mathrm{cms}$ & NA & NA & $72.45 \mathrm{cms}$ \\
\hline
\end{tabular}

The table provides similarities of each, detailing a very comparable discharge rate when analyzing the Power Law solutions to both FEMA and SJRWMD at the 100-yr storm event. The results clearly indicate a variation of estimates but generally show that the Log Pearson Type III approach provides the smallest estimates of flood discharges at three out of the four return frequencies. A visual representation of the estimate spread is included below in Figure 2.

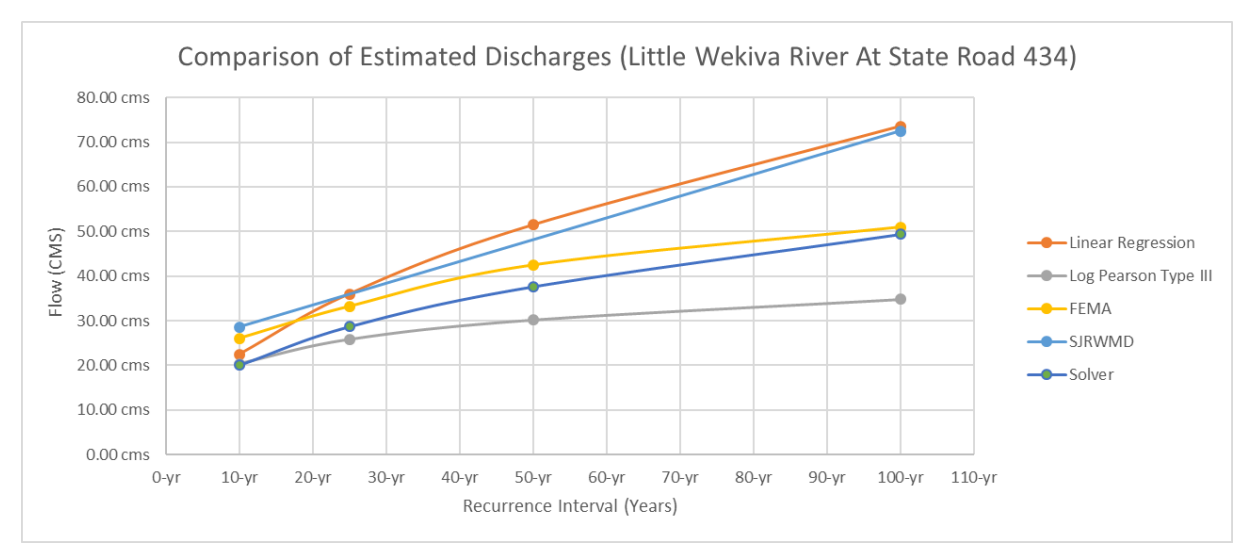

Figure 2. Graphical representation of the estimated flood discharge rates at State Road 434 on Little Wekiva River.

Approaching a way to find discharge estimates along the watercourse is increasingly difficult. However, the support from historical reports will provide a great base and increase the reliability of a certain method when results become similar. In the results given, it can be inferred that the Linear Regression reasonably matches the SJRWMD discharge estimates, while the Solver Non-Linear regression approach closely resembles FEMA's FIS flood discharge estimates. However, the worrisome method is the Log Pearson Type III method that regrettably has been the basis for estimating discharge rates for decades previous. The problem with this method is that it deviates from the published discharge data as the flood frequency decreases. Not only that, but it deviates 
away from becoming conservative and has the potential of putting communities at high flood risks when the Log Pearson Type III outputs are relied upon for engineering design purposes.

\section{Conclusions}

Overall, this study has provided the beginnings of a focused research effort to ensure the development of a reliable statistical equation can approach a watercourse and have the capability to estimate the discharge rates via storm events. The preliminary efforts have provided groundwork that signifies a statistical method can deem accurate results when implemented correctly. Acknowledging that the Power Law method did substantially better in estimating the flow rates when the storm events became larger suggests it may be preferable to its predecessor method.

In summary, this initial effort provided an overview of a system under development in order to simulate flood resiliency in the Wekiva sub-basin. Future tasks to be performed include the final testing, calibration, and validation of the statistical methods employed in a location not yet gaged. Results should be compared to the SJRWMD BASINS model to assess final discharge rates with extreme storm events. Further studies will also be necessary to evaluate the differences between the two Power Law methodologies, namely Linear Regression and Solver Non-Linear Regression.

Author Contributions: W.K. performed the primary research and writing for this article under the mentorship of C.J.B. and C.A. P.K. helped with final article editing. This effort is part of a larger comprehensive research effort led by C.J.B. and C.A. C.J.B. provided the research focus and provided guidance and project administration as well as final editing.

Funding: This research was unfunded and completed by research team as part of a large grant proposal effort.

Acknowledgments: The authors would like to acknowledge help and support from the St. Johns River Water Management District who provided historical model datasets and map coverages used for this study.

Conflicts of Interest: The authors declare no conflict of interest. No one other than the authors had a role in the design of the study; in the collection, analyses, or interpretation of data; in the writing of the manuscript, or in the decision to publish the results.

\section{References}

1. Federal Emergency Management Agency (2013). Flood Insurance Study: Lake County, Florida. (12117CV000A). Retrieved from https://fris.nc.gov/fris/

2. Federal Emergency Management Agency (2014). Flood Insurance Study: Seminole County, Florida. (12069CV000A). Retrieved from https://fris.nc.gov/fris/

3. St. Johns River Water Management District (2012). Chapter 3: Watershed Hydrology. Retrieved from https://www.sjrwmd.com/documents/water-supply/\#wsis

4. St. Johns River Water Management District (2012). St. Johns River Water Supply Impact Study (SJ20120-1). Retrieved from https://www.sjrwmd.com/documents/water-supply/\#wsis@

5. Kidson, R. \& Richards, K. (2005, July 1). Flood frequency analysis: assumptions and alternatives. Progress in Physical Geography, 29(392). Retrieved from https://journals.sagepub.com/doi/abs/10.1191/0309133305pp454ra

6. Oregon State University (2005). Analysis Techniques: Flood Frequency Example with Daily Data (LogPearson Type III Distribution). Retrieved from https://streamflow.engr.oregonstate.edu/analysis/floodfreq/meandaily_example.htm

7. National Oceanic and Atmospheric Administration Atlas 14 (2005). Retrieved from https://hdsc.nws.noaa.gov/hdsc/pfds/pfds_map_cont.html

8. Wekiva Wild and Scenic River System Advisory Management Committee. (2012). Wekiva Wild and Scenic River System Comprehensive Management Plan. Retrieved from https://www.rivers.gov/documents/plans/wekiva-plan.pdf

2020 by the authors. Submitted for possible open access publication under the terms and conditions of the Creative Commons Attribution (CC BY) license (http://creativecommons.org/licenses/by/4.0/). 